\title{
Piotr Błędowski
}

\section{Polityka społeczna jako specjalność nauk o polityce publicznej - próba charakterystyki}

\begin{abstract}
Streszczenie
Artykuł ma na celu omówienie relacji między polityką społeczną a polityką publiczną i wskazanie najważniejszych elementów tych relacji. Polityka społeczna jest związana historycznie z jednej strony z ekonomią, a z drugiej - z socjologią i naukami o polityce. Nauki o polityce publicznej eksponują rolę administracji publicznej w realizacji jej celów i pozwalają na szersze ujęcie zakresu jej zadań poprzez powiązanie ich z innymi specjalnościami. Dzięki temu możliwe jest uzyskanie w praktyce efektów synergicznych podejmowanych działań, a w warstwie teoretycznej - pełniejsza ocena analizowanych problemów. Historia polityki społecznej w Polsce, a szczególnie Instytutu Gospodarstwa Społecznego pokazuje, że takie szerokie podejście do polityki społecznej cechowało tę dyscyplinę także w przeszłości.
\end{abstract}

Słowa kluczowe: polityka społeczna, polityka publiczna, efektywność, innowacje społeczne

Social policy as a field within public policy studies. An introduction

\begin{abstract}
The article aims to discuss the relationship between social policy and public policy and to identify its most important elements. Social policy is linked historically on the one hand with the economy and on the other - with sociology and political sciences. Theory of public policy exposes the role of public administration in achieving its objectives and allows for wider recognition of the tasks by linking them with other specialties. This makes it possible to achieve in practice synergistic effects of actions taken, and at the theoretical level - a more comprehensive assessment of the analyzed problems. The history of social policy in Poland, especially of the Institute of Social Economy shows that such a broad approach to social policy has been characteristic also in the past.
\end{abstract}

Keywords: social policy, public policy, effectiveness, social innovations 
Celem artykułu jest sformułowanie uwag dotyczących miejsca, które polityka społeczna jako specjalność naukowa zajmuje w dyscyplinie naukowej, jaką są nauki o polityce publicznej ${ }^{1}$. Polityka społeczna jest związana historycznie z jednej strony z ekonomią, a z drugiej - z socjologią i naukami o polityce. Ten pierwszy związek jest po dzień dzisiejszy silnie osadzony w niemieckiej tradycji nauk społecznych, gdzie polityka społeczna jest na ogół traktowana jako specjalność w ramach nauk ekonomicznych. Zainteresowanie społeczeństwem, przemianami w jego strukturze i wynikającymi stąd konsekwencjami dla polityki społecznej zaowocowało rozwojem drugiego podejścia, eksponującego bardziej aspekty socjologiczne niż ekonomiczne.

Koncepcja, w myśl której polityka społeczna jest traktowana jako specjalność w dyscyplinie, jaką stanowią nauki o polityce publicznej, stanowi swego rodzaju próbę uporządkowania podejść do polityki społecznej. Polityka społeczna pojawia się bowiem jako specjalność naukowa, której obszar obejmuje styk administracji publicznej i społeczeństwa. Jest to obszar, na którym dochodzi do interakcji między obiema stronami, będący polem realizacji odmiennych niekiedy interesów.

\section{Polityka publiczna - definicja, cele i struktura}

Jeden z prekursorów studiów nad polityką publiczną w Polsce, A. Zybała, definiuje tę politykę jako „zracjonalizowane działania i programy publiczne, które oparte są na zgromadzonej, względnie zobiektywizowanej wiedzy i usystematyzowanym procesie projektowania i wykonywania tych działań”².

Jako politykę publiczną można określać podejmowanie przez administrację publiczną powiązanych ze sobą decyzji i działań z myślą osiągnięcia określonych celów, szczególnie wówczas gdy mechanizmy rynkowe nie mają zastosowania albo same nie mogłyby działać dostatecznie efektywnie ${ }^{3}$. Według B. Guy Petersa, polityka publiczna to ciąg działań, a czasami - braku działań, mających wpływ na życie obywateli. Ta bardzo szeroka definicja pozwala na sformułowanie sugestii, iż politykę publiczną można rozpatrywać jako zespół działań administracji publicznej, wpływających na poziom zaspokojenia potrzeb ludności. Jeśli tak będziemy traktować politykę publiczną, to możemy wskazać jej cele. Należą do nich między innymi:

1 J. Woźnicki, Nowa dyscyplina - „nauki o polityce publicznej” usytuowana $w$ dziedzinie nauk społecznych, „Nauka” 2012, nr 1, s. 141.

2 A. Zybała, Polityki publiczne. Doświadczenia w tworzeniu i wykonywaniu programów publicznych $w$ Polsce $i$ w innych krajach, KSAP, Warszawa 2012, s. 24.

3 J. Woźnicki, op.cit., s. 133.

4 B. Guy Peters, American Public Policy. Promise and Performance, CQPress, Thousand Oaks 2004, s. 4-6. Za: A. Zybała, op.cit., s. 24. 
- realizacja postanowień zawartych w aktach prawnych uchwalanych na różnych szczeblach,

- rozpoznawanie i diagnozowanie potrzeb, których zaspokojenie wymaga współudziału organów administracji publicznej,

- definiowanie zadań dla poszczególnych instytucji państwowych i samorządowych,

- świadome kształtowanie postaw lokalnych społeczności,

- wykorzystanie kapitału i potencjału społecznego.

Analiza podejmowanych działań powinna umożliwić wskazanie w procesie realizacji polityki publicznej następujących etapów: 1) internalizacja problemu; 2) ustalenie celów i dróg rozwiązania problemu; 3) wybór metody analizy problemu; 4) dobór kryteriów oceny rozwiązań; 5) ustalenie alternatywnych rozwiązań problemu; 6) ocena konsekwencji wyboru poszczególnych wariantów ${ }^{5}$. Jak widać, polityka publiczna koncentruje się również na procesie rozwiązywania problemu, a nie tylko na samym problemie. Ta cecha w istotny sposób odróżnia ją od polityki społecznej, dotykającej przede wszystkim istoty problemu, ale nie zajmującej się koniecznie sposobami jego praktycznego rozwiązywania.

Jeśli wziąć pod uwagę obszary polityki publicznej, to można dostrzec, że dotyczą one przede wszystkim samego procesu podejmowania decyzji i jej efektów (produktów). Podejmowanie decyzji następuje przy wykorzystaniu instrumentów naukowych i naukowej oceny stanu potrzeb, zarówno całego społeczeństwa czy lokalnej społeczności, jak i działań na rzecz społeczeństwa lub jego grupy. Taki punkt widzenia prezentuje R. Szarfenberg, który odwołuje się do przedstawianej w literaturze typologii obszarów polityki publicznej (rysunek 1).

Jak można odczytać z rysunku, nauka o polityce społecznej obejmuje obszary związane z jej treścią, realizacją, efektami w postaci produktów oraz wynikami. Punktem wyjścia jest zatem zawartość aktów prawnych, nie tylko regulujących stan obecny, ale i formułujących plany i zamiary na przyszłość. Dotyczy to w szczególności strategii i programów, uchwalanych przez podmioty władzy i instytucje szczebla krajowego, regionalnego oraz lokalnego. Zwłaszcza ta druga grupa dokumentów - strategii, skierowanych na przyszłość - może być podstawą działania polityki publicznej. Ponadto ważną rolę mogą odgrywać opinie ekspertów, praktyków i osób zaangażowanych w realizację zadań polityki publicznej.

Proces realizacji polityki publicznej w odniesieniu do konkretnego problemu rozpoczyna się $\mathrm{w}$ chwili sformułowania idei: $\mathrm{w}$ rezultacie dyskusji koncepcja zmiany nabiera coraz bardziej konkretnych kształtów i dochodzi do podejmowania decyzji

5 R. Szarfenberg, Miejsce polityki społecznej w polityce publicznej. Ekspertyza na potrzeby projektu Kalkulator Kosztów Zaniechania, Warszawa 2013, maszynopis. 
(od strategicznych po szczegółowe). Poszczególne decyzje są realizowane przy wykorzystaniu instrumentów poszczególnych dziedzin polityki składających się na specjalności w ramach nauki o polityce publicznej.

\begin{tabular}{|c|c|c|c|c|c|c|c|}
\hline \multicolumn{4}{|c|}{ Nauka o polityce publicznej } & \multicolumn{4}{|c|}{ Nauka dla polityki publicznej } \\
\hline $\begin{array}{l}\text { Treść } \\
\text { polityki } \\
\text { publicznej } \\
\text { - zawarta } \\
\text { w stra- } \\
\text { tegiach, } \\
\text { aktach } \\
\text { prawnych, } \\
\text { opiniach } \\
\text { praktyków }\end{array}$ & $\begin{array}{l}\text { Proces } \\
\text { polityki } \\
\text { publicznej } \\
\text { - od pow- } \\
\text { stawania } \\
\text { idei poprzez } \\
\text { decydowa- } \\
\text { nie, wdraża- } \\
\text { nie ich oraz } \\
\text { kończenie } \\
\text { procesu }\end{array}$ & $\begin{array}{l}\text { Produkt } \\
\text { polityki } \\
\text { publicznej } \\
\text { - narzędzia } \\
\text { i instrumenty } \\
\text { polityki } \\
\text { w praktyce, } \\
\text { np. usługi } \\
\text { publiczne, } \\
\text { ich finan- } \\
\text { sowanie }\end{array}$ & $\begin{array}{l}\text { Wyniki } \\
\text { polityki } \\
\text { publicznej } \\
\text { - wpływ } \\
\text { polityki } \\
\text { na problemy, } \\
\text { które miała } \\
\text { rozwiązać }\end{array}$ & $\begin{array}{l}\text { Wyniki ewa- } \\
\text { luacji polityki } \\
\text { publicznej } \\
\text { i rekomenda- } \\
\text { cje na ich } \\
\text { podstawie }\end{array}$ & $\begin{array}{l}\text { Gromadze- } \\
\text { nie i analiza } \\
\text { danych } \\
\text { w celu } \\
\text { wspo- } \\
\text { magania } \\
\text { decyzji } \\
\text { dotyczących } \\
\text { polityki } \\
\text { publicznej }\end{array}$ & $\begin{array}{l}\text { Doradzanie } \\
\text { na rzecz } \\
\text { usprawnie- } \\
\text { nia procesu } \\
\text { polityki } \\
\text { publicznej }\end{array}$ & $\begin{array}{l}\text { Rzecznictwo } \\
\text { konkretnych } \\
\text { rozwiązań } \\
\text { w polityce } \\
\text { publicznej }\end{array}$ \\
\hline
\end{tabular}

\section{Rysunek 1. Typologia podstawowych obszarów nauki o i dla polityki publicznej}

Źródło: B.W. Hogwood, L.A. Gunn, Policy Analysis for the Real World, 1984, s. 29. Za: R. Szarfenberg, Nauki o polityce społecznej a nauki o polityce publicznej, http://rszarf.ips.uw.edu.pl/pdf/nopp_nops.pdf, s. 11, dostęp 20.10.2014.

Wśród narzędzi i instrumentów polityki publicznej szczególne miejsce przypada usługom społecznym. Ogólnie usługi społeczne można określić jako działania mające na celu poprawę zdolności umysłowych i fizycznych jednostki. W miarę postępu ich personalizacji i profesjonalizacji, usługi można uznać za jeden z bardziej efektywnych i skutecznych zarazem instrumentów polityki społecznej. Jego znaczenie wynika stąd, że usługi te bezpośrednio aktywizują osobę z nich korzystającą, a ponadto wpływają na podniesienie poziomu jej kapitału ludzkiego. Biorąc pod uwagę najważniejsze cechy usług społecznych, podkreślić należy ich indywidualizację oraz zapewnienie odpowiednio rozbudowanej infrastruktury społecznej jako jedne z warunków ich skuteczności 6 .

Wskazane powyżej elementy obszaru nauki o polityce publicznej są istotne ze względu na ich wpływ na zidentyfikowane problemy społeczne. Sama umiejętność oddziaływania na otoczenie społeczne wymaga jednak dobrej znajomości teorii oraz praktyki polityki społecznej. W tym kontekście należy zwrócić uwagę na drugą część schematu, pokazującą możliwe obszary wpływu innych nauk na wzbogacanie dorobku polityki publicznej. Jako podsumowanie tej części rozważań można zacytować słowa J. Woźnickiego, który w następujący sposób charakteryzuje istotę nauki o polityce

6 J. Rokicki, Usługi społeczne jako przedmiot badań (pojęcie, cechy, rodzaje i funkcje), „Polityka Społeczna” 2014, nr 7, s. 5. 
publicznej: „Polityka publiczna służy nadawaniu porządku zadaniom publicznym, od ich projektowania, poprzez realizowanie, aż do oceny wyników. Politykę publiczną można określić jako zbiór procesów, których realizację podejmuje administracja w ramach swej misji zaspokajania potrzeb publicznych. Oznacza to, że cele polityki publicznej wskazywane są przez szeroko pojmowane podmioty sprawujące władzę (w tym także organy władzy ustawodawczej), a konkretyzacja i wykonywanie zadań powierzane są organom administracji publicznej"

\section{Polityka społeczna - definicje, cele i zakres działania w kontekście polityki publicznej}

Przez całe poprzednie stulecie polityka społeczna jako dyscyplina naukowa dorobiła się wielu definicji ${ }^{8}$. Wprawdzie różnią się one i zakresem zadań, i celami, i wreszcie określeniem podmiotów odpowiedzialnych za ich realizację, ale generalnie można przyjąć, że zadaniem polityki społecznej, realizowanej przy decydującym współudziale państwa, jest kształtowanie struktur społecznych sprzyjających postępowi społecznemu. Według A. Kurzynowskiego, „polityka społeczna to działalność państwa, samorządu i organizacji pozarządowych zmierzająca do kształtowania ogólnych warunków pracy i bytu ludności, prorozwojowych struktur społecznych oraz stosunków społecznych opartych na równości i sprawiedliwości społecznej, sprzyjających zaspokajaniu potrzeb społecznych na dostępnym poziomie" ${ }^{\text {" Takie }}$ określenie polityki społecznej zakłada, że zaspokajanie potrzeb społecznych nie jest wyłącznie domeną podmiotów polityki społecznej. Te ostatnie mają raczej pomagać w tworzeniu warunków korzystnych do zaspokajania potrzeb, a nie wyręczać samych zainteresowanych i innych uczestników procesów społecznych. Sprzyja to upodmiotowieniu jednostek, rodzin i małych grup społecznych.

Tego rodzaju podejście do polityki społecznej nie zostało ukształtowane dopiero po okresie transformacji ustrojowej i społecznej, ale było obecne w polskiej myśli społecznej już prawie 100 lat temu. Powstały w 1920 r. Instytut Gospodarstwa Społecznego odegrał bardzo istotną rolę w utrwalaniu poglądu, iż zadaniem polityki społecznej jest kształtowanie struktury społecznej w sposób sprzyjający postępowi

7 J. Woźnicki, op.cit., s. 134.

8 Zob. obszerny artykuł na temat definicji polityki społecznej i ich systematyzacji R. Szarfenberg, Definicje polityki społecznej, w: Wokół teorii polityki społecznej, red. B. Rysz-Kowalczyk, B. Szatur-Jaworska, IPS UW, Warszawa 2003, s. 31 i nast.

9 A. Kurzynowski, Związki polityki społecznej z polityka gospodarcza, w: Polityka społeczna, red. A. Kurzynowski, Oficyna Wydawnicza SGH, Warszawa 2001, s. 11. 
społecznemu. Tacy socjologowie i politycy społeczni, jak Konstanty Krzeczkowski, Ludwik Krzywicki, Stanisław Rychliński wpłynęli na sposób myślenia o polityce społecznej kolejnych pokoleń badaczy zajmujących się tą problematyką ${ }^{10}$. Ich myśl została rozwinięta przez kolejne pokolenia polityków społecznych, a zwłaszcza Antoniego Rajkiewicza, Michała Olędzkiego i Adama Kurzynowskiego, eksponujących w swoich badaniach i publikowanych pracach problem rozwoju oraz czynników go warunkujących. Ich dorobek i sposób podejścia do polityki społecznej można potraktować jako prekursorski w stosunku do polityki publicznej.

Zakres zainteresowania polityki społecznej jako dyscypliny teoretycznej oraz jej działania w praktyce życia społecznego ulegają systematycznemu rozszerzaniu. O ile początkowo zadania podmiotów państwowych koncentrowały się na polityce socjalnej, to w drugiej połowie XX w. objęły na całym świecie coraz więcej zadań związanych z funkcjonowaniem społeczeństwa w zmieniających się warunkach gospodarowania oraz podlegającym przeobrażeniu systemie norm społecznych i wartości. Wykształcone z czasem szczegółowe segmenty polityki społecznej obejmują praktycznie cały zakres funkcjonowania społeczeństwa ${ }^{11}$, odwołują się do różnych instrumentów, składają się na kompleks działań adresowanych do społeczeństwa jako całości, poszczególnych grup społecznych i zawodowych, rodzin oraz jednostek. Narzędzia te służą realizacji zaplanowanych celów. Jak wspomniano przy okazji zarysowania problematyki polityki publicznej, jej narzędzia są używane wówczas, gdy mechanizmy rynkowe nie mogą działać lub ich zastosowanie byłoby niecelowe ${ }^{12}$. Tak się dzieje na przykład w wypadku dostępu do świadczeń zdrowotnych, edukacyjnych czy związanych z opieką nad osobą niesamodzielną. Skorzystanie z mechanizmów rynkowych mogłoby spowodować wzrost cen odpowiednich usług, a zatem i ograniczenie dostępu do świadczeń. W celu zapewnienia sprawiedliwego dostępu do świadczeń państwo podejmuje decyzje dotyczące sposobu finansowania tego rodzaju usług, ich podaży oraz możliwości korzystania z nich.

Działania te następują jednak w pewnym kontekście - składają się nań zdefiniowane cele polityki społecznej. Innymi słowy, realizacja zadań w ramach wybranej polityki szczegółowej następuje z uwzględnieniem generalnych celów, nakreślonych

10 Por. K. Krzeczkowski, Problemat polityki społecznej, Instytut Spraw Społecznych, Warszawa 1936; J. Hrynkiewicz, Kwestia społeczna w pracach Ludwika Krzywickiego, Wydawnictwo UW, Warszawa 2010; M. Cesarski, Zagadnienia mieszkaniowe i osadnicze w pracach Ludwika Krzywickiego i ich aktualność, „Człowiek i Środowisko” 2010, nr 3-4; S. Rychliński, Lustracje społeczne, Aspra-JR, Warszawa 2001.

${ }^{11}$ Przykładowo można wymienić nie tylko zabezpieczenie społeczne (czyli w praktyce politykę socjalną), ale i politykę ochrony zdrowia, ochrony pracy, zatrudnienia, ochrony środowiska naturalnego, edukacyjną, kulturalną, organizacji czasu wolnego, rodzinną, ale także politykę adresowaną do konkretnych populacji: młodzieży czy osób starszych.

12 J. Woźnicki, op.cit., s. 133. 
w dokumentach strategicznych. Cele te uwzględniają uznany za pożądany i możliwy do osiągnięcia w określonej perspektywie czasu poziom życia i jego jakość.

Współczesna polityka społeczna jest polityką wymagającą innowacyjnego podejścia. Wynika to nie tylko z konsekwencji zmian demograficznych w społeczeństwie, ale $\mathrm{z}$ trudniejszego dostępu do zasobów (ważną rolę w tym ograniczeniu odegrał kryzys finansów publicznych, który ujawnił się w roku 2008 i spowodował liczne przewartościowania w dotychczasowych celach polityki społecznej) ${ }^{13}$. Wobec koniecznych większych wydatków ze środków publicznych oraz wobec realnej groźby ograniczenia możliwości finansowania kolejnych wydatków należałoby oczekiwać, że szerokie wprowadzenie innowacji w polityce społecznej powinno umożliwić zastosowanie w praktyce życia społecznego nowych, uwzględniających zachodzące zmiany, rozwiązań. Powinny one reagować na potrzeby społeczne bardziej efektywnie niż dotychczasowe oraz umożliwić wykreowanie lub poprawę istniejących więzi społecznych, a także ułatwić lepsze wykorzystanie posiadanych zasobów ${ }^{14}$.

Określenie „inwestycje społeczne” zyskuje coraz większą popularność w literatu$\mathrm{rze}^{15}$. Wydatki na rozwiązanie lokalnych problemów społecznych można traktować jako inwestycje, których celem jest osiągnięcie zrównoważonego rozwoju społecznego w skali lokalnej. Cel ten - od momentu poczynienia wspomnianych wydatków - może okazać się dość odległy w czasie, ale przynosi oczekiwane (choć nie zawsze wymierne) skutki, toteż przeniesienie terminu „inwestycja” z języka ekonomii wydaje się całkiem uzasadnione. Takie rozumienie wydatków społecznych powinno sprzyjać zmniejszeniu presji na szybkie osiąganie zmiany sytuacji, co najczęściej nie jest możliwe lub nie zapewnia trwałej poprawy sytuacji.

W literaturze polskiej od kilku lat pojawiają się określenia „aktywna polityka społeczna” ${ }^{16} \mathrm{i}$ „aktywizująca polityka społeczna” ${ }^{17}$. Zwłaszcza termin „aktywizująca

${ }_{13}$ Zob. np. P. Błędowski, Zmiany w systemie polityki społecznej, w: Transformacja systemowa w Polsce, red. K. Żukrowska, Oficyna Wydawnicza SGH, Warszawa 2010; P. Błędowski, Polityka społeczna wobec konsekwencji starzenia się ludności, w: Kryzys i co dalej?, red. I. Lichniak, Oficyna Wydawnicza SGH, Warszawa 2012; P. Błędowski, Sfera socjalna w warunkach kryzysu, w: Kryzys gospodarczy 2008+ test dla stosowanej polityki. Metody przeciwdziałania i ich skuteczność, red. K. Żukrowska, Oficyna Wydawnicza SGH, Warszawa 2013.

${ }^{14}$ J. Caulier-Grice, A. Davis, R. Patrick, W. Norman, Defining Social Innovation. A deliverable of the project: "The theoretical, empirical and policy foundations for building social innovation in Europe" (TEPSIE), European Commission - 7th Framework Programme, European Commission, DG Research, Brussels 2012.

${ }_{15}$ Zob. np. N. Morel, B. Palier, J. Palme, Towards a social investment welfare state? Ideas, policies and challenges. The Policy Press University of Bristol, Bristol 2012; J. Hochgerner, Conceptualising social innovation, https://www.zsi.at/attach/Hochgerner_Madrid_7-3-2012_ppt.

16 T. Kaźmierczak, M. Rymsza, Aktywna polityka społeczna. Stan obecny i szanse upowszechnienia koncepcji. „Analizy i Opinie” 2005, nr 48, Instytut Spraw Publicznych, Warszawa.

17 Por. m.in. Aktywizująca polityka społeczna, red. J. Orczyk, M. Żukowski, „Zeszyty Naukowe” 2007, nr 89, Wydawnictwo Akademii Ekonomicznej w Poznaniu; A. Karwacki, Papierowe skrzydła. 
polityka społeczna" trafnie oddaje istotę współczesnych zmian w sposobach i formach działania polityki społecznej: tam, gdzie jest to możliwe i wskazane, powinno się stosować formy aktywizujące słabe ekonomicznie grupy ludności z myślą o ich usamodzielnieniu. Podejmowane w ramach samorządowych programów wysiłki na rzecz poprawy sytuacji konkretnych grup ludności zakładają między innymi wszechstronne korzystanie z usług społecznych i wspomagających je świadczeń materialnych w celu osiągnięcia takiej sytuacji, w której klient pomocy społecznej zostanie trwale usamodzielniony lub - przynajmniej - zakres wsparcia, z którego korzysta, będzie mógł zostać ograniczony bez uszczerbku dla sytuacji jednostki i jej rodziny. Działania te można rozpatrywać zarówno z perspektywy polityki społecznej, koncentrując się na przykład na sytuacji życiowej tych grup, jak i z punktu widzenia całej nauki o polityce publicznej, skupiając uwagę na działaniach aktywizujących i podmiotach je podejmujących.

Polityka społeczna określana jest w ostatnich latach - co łatwo można dostrzec, analizując tytuły publikacji naukowych - przez coraz większą liczbę przymiotników. Poza innowacyjną, aktywną i aktywizującą polityką społeczną mówi się m.in. o inwestycyjnej polityce społecznej. Problem nie jest nowy, bo już pod koniec lat 70. $\mathrm{XX}$ w. powstała obszerna praca naukowa poświęcona polityce społecznej bliskiej obywatelowi ${ }^{18}$. Czwarty rozdział tej książki nosi tytuł (w tłumaczeniu na język polski) Udzielanie świadczeń przez instytucje i placówki a społeczne problemy ludności. Biorąc pod uwagę istotę nauk o polityce publicznej, można by tę pracę traktować jako jedną z pierwszych lokujących politykę społeczną w dyscyplinie polityki publicznej. Przemawia za tym nie tylko tytuł rozdziału, wskazujący na znaczenie relacji między administracją publiczną a jednostką, ale i cała jego treść, nawiązująca do zadania skutecznego rozwiązywania problemów społecznych przy wykorzystaniu różnych instrumentów polityki społecznej i wzięciu pod uwagę kosztów związanych z ich stosowaniem. Praca ta jest prekursorska, a ponadto - co bardzo ważne - zachowała aktualność po dzień dzisiejszy.

W obszarze polityki publicznej i polityki społecznej można wskazać następujące istotne relacje między polityką społeczną a polityką publiczną ${ }^{19}$ :

- miejsce polityki społecznej w polityce publicznej widzianej z perspektywy procesów decentralizacji państwa jest dwoiste. Z jednej strony najważniejszy obszar polityki społecznej minionego wieku, jakim były ubezpieczenia społeczne, podlega dalej

Rzecz o spójnej polityce społecznej, Wydawnictwo UMK, Toruń 2010; M. Rymsza, Aktywizacja w polityce społecznej. W stronę rekonstrukcji europejskich welfare states?, Wydawnictwo IFiS PAN, Warszawa 2013. 18 Bürgernahe Sozialpolitik. Planung, Organisation und Vermittlung soziale Leistungen auf lokaler Ebene, Hrsg. F.-X. Kaufmann, Campus-Verlag 1979.

19 R. Szarfenberg, op.cit., s. 42-43. 
idącemu scentralizowaniu, co wynika przede wszystkim z technicznego charakteru prowadzonych operacji (ewidencjonowanie składek, wypłacanie świadczeń pieniężnych w dobrze zdefiniowanych sytuacjach ryzyka socjalnego). Równocześnie można stwierdzić, że pozostałe ważne obszary współczesnej polityki społecznej zostały w Polsce zdecentralizowane. Przykładami mogą być działania nakierowane na integrację społeczną, w tym usługi dla bezrobotnych, pomoc społeczna, a także wsparcie rodziny. Dlatego też - zdaniem R. Szarfenberga - w tym drugim wypadku dochodzi do rosnącego znaczenia rządzenia zarówno w skali pionowej (rządzenie między władzą i administracją rządową a samorządową), jak i poziomej (rządzenie pomiędzy niezależnymi poziomami samorządu, rządzenie z udziałem partnerów społecznych, organizacji obywatelskich);

- polityczne znaczenie polityki społecznej w obszarze spraw polityki publicznej, związane z działaniami bezpośrednio wpływającymi na poziom życia ludności, jest i pozostanie w przyszłości duże. Przykładem tego są trwające dyskusje nad sposobami zwalczania bezrobocia, ubóstwa i wykluczenia społecznego;

- polityka rozwoju może mieć większy potencjał jako przedmiot analiz i działalności praktycznej analityków niż wąsko ujmowana polityka społeczna (a zwłaszcza socjalna). Politykę socjalną cechuje ograniczenie do świadczeń, a nie całościowe podejście, niezbędne podczas realizowania koncepcji polityki nastawionej na rozwój społeczny.

Szukając odpowiedzi na pytanie o miejsce polityki społecznej w polityce publicznej należałoby przeanalizować stanowisko J. Woźnickiego, porządkującego wiedzę na temat strukturalnych aspektów nauki o polityce publicznej ${ }^{20}$. Według tego autora, wśród specjalności nowej dyscypliny wiedzy można wyróżnić specjalność, jaką stanowi polityka społeczna. Autor wskazuje cztery specjalizacje, wchodzące w jej skład. Należą do nich: polityka społeczna (w tym np. polityka ludnościowa i rodzinna, polityka rynku pracy i prawa pracy, polityka zabezpieczenia społecznego, polityka usług osobistych i socjalnych, polityka wobec kościołów i związków wyznaniowych oraz mniejszości narodowych i etnicznych), zdrowotna, mieszkaniowa oraz polityka w zakresie rozwoju kultury fizycznej, sportu i turystyki. Wśród specjalizacji zaliczonych do innych specjalności można odnaleźć m.in. politykę edukacyjną oraz politykę ochrony środowiska. W ten sposób niemal cały zestaw dziedzin szczegółowych wchodzących w skład polityki publicznej znalazł się w strukturze specjalizacji nowej dyscypliny.

Oczywiście, można dyskutować, czy oznacza to całkowite odejście od stosowanego wcześniej przyporządkowania polityki społecznej do dyscyplin, jakimi są socjologia,

20 J. Woźnicki, op.cit., s. 142. 
nauki polityczne lub ekonomia. Wydaje się, że zaproponowane włączenie polityki społecznej do nauk o polityce publicznej ma swoje uzasadnienie wynikające ze specyfiki jej funkcjonowania na styku administracja publiczna - społeczeństwo (urząd - obywatel), ale analiza naukowa będzie nadal mogła być prowadzona również z perspektywy wymienionych wyżej dyscyplin naukowych.

Co zatem przemawia za usytuowaniem polityki społecznej w dyscyplinie nauk o polityce publicznej? By odpowiedzieć na to pytanie, wybrałem z wielokrotnie już cytowanego (bo praktycznie konstytuującego tę dyscyplinę) artykułu J. Woźnickiego kilka cytatów, najlepiej, w moim odczuciu, charakteryzujących nauki o polityce publicznej. Według eksperta, „Badania nad polityką publiczną, ze względu na znaczną liczbę polityk sektorowych, wymagają podejścia interdyscyplinarnego. Wynika to $\mathrm{z}$ faktu, iż sam proces formułowania treści polityk publicznych, ich implementacji oraz ewaluacji, angażuje rozmaite dyscypliny nauki (obszary wiedzy) - politycznej, zarządczej, prawniczej, socjologicznej, ekonomicznej oraz sektorowej”21 . Otóż, polityka społeczna jest nauką, dla której podejście interdyscyplinarne jest konieczne. Ponadto, system polityki społecznej, z uwagi na liczne dziedziny szczegółowe, charakteryzuje się bardzo silną, choć zróżnicowaną w ich obrębie, tendencją do interdyscyplinarności. Na marginesie warto zwrócić uwagę, że taka właściwa polityce społecznej tendencja do interdyscyplinarności wyraża się także w warstwie praktycznej polityki, zwłaszcza wówczas, gdy postuluje się wielosektorowy sposób jej realizacji ${ }^{22}$. Ta podkreślana interdyscyplinarność nawiązuje także do wspomnianego usytuowania nauki o polityce społecznej w takich dyscyplinach, jak socjologia, nauki polityczne i ekonomia. W żadnej z tych dyscyplin nie mógł być prowadzony dyskurs naukowy wyłącznie z jej perspektywy i z pominięciem pozostałych. Można zatem bez obawy o popełnienie błędu powiedzieć, że skłonność do interdyscyplinarnego oglądu przedmiotu swoich działań, formułowania diagnozy i doboru instrumentów cechuje politykę społeczną od początku jej istnienia jako specjalności naukowej.

Jeżeli odwołać się do cech polityki publicznej, to A. Zybała wskazuje na jej elementy ujawniające się podczas prowadzenia profesjonalnych działań publicznych ${ }^{23}$. Może zestawić je z cechami racjonalnych działań podejmowanych w ramach polityki społecznej, szczególnie na poziomie lokalnym. Jak można zauważyć na podstawie lektury tabeli 1, istnieje wiele podobieństw między cechami polityki publicznej i społecznej.

${ }^{21}$ Ibidem, s. 140.

22 Por. M. Grewiński, Wielosektorowa polityka społeczna. O przeobrażeniach państwa opiekuńczego, WSP TWP, Warszawa 2009.

23 Obszernie na ten temat zob. A. Zybała, Państwo i społeczeństwo w działaniu. Polityki publiczne wobec potrzeb modernizacji państwa i społeczeństwa, Wydawnictwo Difin, Warszawa 2013. 
Tabela 1. Zestawienie cech polityki publicznej i polityki społecznej

\begin{tabular}{|l|}
\multicolumn{1}{|c}{ Polityka publiczna } \\
Profesjonalne działania publiczne
\end{tabular}

Zorientowane na zewnątrz. Działania publiczne mają uwzględniać czynniki oraz zjawiska występujące w kraju, na kontynencie i na świecie. Powinny efektywnie komunikować treść programów publicznych.

Innowacyjne i kreatywne. Działania publiczne mają kwestionować tradycyjne sposoby radzenia sobie z problemami, wspierać nowe pomysły, być otwarte na opinie i sugestie innych.

Oparte na dowodach. Działania publiczne mają opierać się na nailepszych dostępnych dowodach z najszerszych źródeł oraz włączać interesariuszy na każdym etapie prac.

Inkluzyjne. Działania publiczne mają uwzględniać potrzeby wszystkich, którzy zostaną dotknięci ich wpływem.

\author{
Polityka społeczna \\ Racjonalne działania w skali lokalnej
}

Prewencja zamiast interwencji. Działania mają być zorientowane na zapobieganie trudnym sytuacjom powodującym potrzebę interwencji i antycypować możliwy do określenia na podstawie analiz trendów i badań empirycznych rozwój procesów społecznych w przyszłości.

Uwzględnia rolę czynników zewnętrznych. Polityka społeczna uwzględnia nie tylko zróżnicowanie przestrzenne, ale i wpływ innych niż społeczne (np. ekonomiczne i polityczne) czynników, procesów i zjawisk.

Innowacyjna polityka społeczna. Nowe rozwiązania nowych problemów. Wobec zmiany warunków funkcjonowania społeczeństwa i warunków gospodarowania konieczne jest poszukiwanie nowych, a często i szybko zmieniających się oraz dostosowanych do kolejnych zmian instrumentów.

Racjonalna. Ze względu na potrzebę racjonalnego gospodarowania zasobami działania polityki społecznej muszą wykorzystywać sprawdzone oraz poparte naukowymi analizami instrumenty i techniki. Konieczne jest precyzyjne oszacowanie spodziewanych efektów działań jako ważne kryterium podejmowania decyzji.

Walka z ekskluzją społeczną. Działania polityki społecznej powinny być nakierowane na zwalczanie i zapobieganie wykluczeniu społecznemu. Działania powinny być weryfikowane pod kątem ich wpływu na zjawisko ekskluzji. Nowsze programy polityki społecznej w coraz większym stopniu uwzględniają jako cel inkluzję społeczną.

\section{Zintegrowane. Działania publiczne mają wychodzić poza instytucjonalne bariery i orientować się na strategiczne cele rządu. W programowaniu działań ważna jest podstawa prawna i etyczna.}

\section{Koordynacja. Ze względu na wielość podmiotów} i tendencję do wielosektorowego rozwiązywania problemów społecznych na znaczeniu zyskuje zadanie koordynacji działań tak, by składały się one na spójny i racjonalny program.

Ewaluowane. Działania publiczne mają zawierać
mechanizmy systemowej oceny ich wyników.

Ewaluacja w polityce społecznej. Jeden z warunków racjonalności działań i stałej kontroli nad zgodnością podjętych działań ze zdiagnozowanymi potrzebami.

\begin{tabular}{|l|l|}
\hline $\begin{array}{l}\text { Poddawane przeglądom. Działania publiczne mają być } \\
\text { poddawane przeglądom służącym analizie pozwalającej } \\
\text { ocenić, czy nadal są one zorientowane na rozwiązanie } \\
\text { założonych problemów publicznych i wskazywaniu } \\
\text { efektów działań, które występują w różnych } \\
\text { sferach/dziedzinach. }\end{array}$ & $\begin{array}{l}\text { Kontrola społeczna. Jest to jeden z podstawowych } \\
\text { warunków uspołecznienia polityki społecznej oraz } \\
\text { weryfikacji podejmowanych działań z punktu widzenia } \\
\text { ich skuteczności oraz skuteczności stosowanych } \\
\text { instrumentów, ważna podstawa prawna i etyczna. }\end{array}$ \\
\hline $\begin{array}{l}\text { Oparte na uczeniu się. Działania publiczne mają } \\
\text { zakładać stały proces uczenia się wykorzystującego } \\
\text { dobre doświadczenia z podjętych działań } \\
\text { i pozwalającego unikać niekorzystnych konsekwencji. }\end{array}$ & $\begin{array}{l}\text { Nowa jakość działania. Stanowią ją: weryfikacja } \\
\text { programów, ich porównywanie z podobnymi realizowanymi } \\
\text { w innych regionach oraz dyskusja nad efektami } \\
\text { podejmowanych działań i ich zgodnością z oczekiwaniami. }\end{array}$ \\
\hline
\end{tabular}

Źródło: kolumna dotycząca polityki publicznej A. Zybała, Polityki publiczne. Doświadczenia w tworzeniu $i$ wykonywaniu programów publicznych $w$ Polsce $i$ w innych krajach, KSAP, Warszawa 2012, s. 29; kolumna dotycząca polityki społecznej - opracowanie własne. 
Jak widać z powyższej tabeli, ogólnym cechom polityki publicznej jako nauki odpowiadają cechy teorii polityki społecznej. Zachodzi zgodność, lub przynajmniej daje się zaobserwować znaczne podobieństwo, cech charakteryzujących dyscyplinę i lokowaną w jej ramach specjalność. Podobny sposób postrzegania problemów, ich interpretacji oraz spojrzenie w przyszłość uprawniają do tego, by zaakceptować propozycję nowego usytuowania nauki o polityce społecznej w systemie dyscyplin naukowych.

Odnosząc się do miejsca polityki społecznej w dyscyplinie nauk o polityce publicznej, należy wziąć pod uwagę nie tylko dotychczasowy dorobek naukowy, ale również perspektywy badawcze specjalności, postrzegane z pozycji dyscypliny naukowej. Wydaje się, że można wskazać cztery istotne cechy badań w obszarze polityki społecznej, które mogą zostać spożytkowane przez całą dyscyplinę. Są nimi:

- interdyscyplinarność: obecnie i w przyszłości interdyscyplinarność powinna być rozumiana szeroko. Powinna dotyczyć nie tylko dorobku naukowego innych dyscyplin, ale także stosowania w praktyce badawczej takich metod i technik, które pozwalają na lepsze zdiagnozowanie problemu. Techniki te mogą być zaczerpnięte nie tylko z dziedziny nauk społecznych. Dobrym przykładem takiego rozwiązania jest projekt badawczy „Kalkulator Kosztów Zaniechania w polityce społecznej", który w warstwie rachunkowej odwołuje się do narzędzi ekonometrycznych i informatycznych ${ }^{24}$;

- możliwości implementacji: są one coraz większe, zwłaszcza wówczas, gdy proponowane działania w sferze społecznej są oparte na wynikach badań i analiz wykorzystujących doświadczenia zebrane w innych społecznościach lub społeczeństwach; uwzględniają aspekty ekonomiczne, a zwłaszcza efektywność planowanych działań, ale równocześnie nie traktują czynników ekonomicznych w sposób bezkrytyczny i odnoszą je do tych adresatów działań, w wypadku których instrumenty ekonomiczne mają sens;

- próba oceny efektywności lub skuteczności: w wypadku polityki społecznej, zwłaszcza tej realizowanej na szczeblu samorządowym, bardziej uzasadnione wydaje się ocenianie skuteczności polityki niż jej efektywności. Dotyczy to zwłaszcza pomocy społecznej, której rezultatem często nie może być usamodzielnienie jednostki ze względu na jej wiek, stan zdrowia, kwalifikacje, sytuację na lokalnym rynku pracy czy podobne czynniki. Brak efektu w postaci trwałego usamodzielnienia środowiska korzystającego ze wsparcia nie może powodować zaprzestania udzielania pomocy. W przyszłości warto jednak postarać się o określenie wpływu

${ }^{24}$ Zob. Kalkulator Społeczny - narzędzie Kalkulatora Kosztów Zaniechania w polityce społecznej, „Polityka Społeczna” 2014, zeszyt tematyczny 3. 
poszczególnych czynników na skuteczność udzielanych świadczeń tak, by w pierwszej kolejności skoncentrować się na tych, które dają potencjalnie największe szanse na trwałą poprawę sytuacji;

- aspekty ekonomiczne: w kontekście wyżej sformułowanych uwag należy podkreślić, że koncentracja na skuteczności wsparcia nie zwalnia podmiotów polityki społecznej i polityki publicznej z dbałości o osiągnięcie możliwie wysokiej efektywności udzielanych świadczeń. O ile jest to znacznie trudniejsze w wypadku typowych instrumentów pomocy społecznej, jak na przykład zasiłki pieniężne, o tyle należałoby szczególnie zatroszczyć się o efektywność usług społecznych. Sprzyja temu ich indywidualizacja, co pozwala na uniknięcie udzielania świadczeń niedostosowanych do specyficznej sytuacji jednostki. We wszystkich skalach - makro, mezo i mikro - aspekty ekonomiczne powinny odgrywać ważną rolę jako kryteria podejmowania decyzji.

Podsumowując powyższe rozważania, należy podkreślić, iż zmiana ulokowania nauki o polityce społecznej wśród dyscyplin naukowych nie oznacza zmiany jej systemu aksjologicznego, podstawowych instrumentów oraz kryteriów ewaluacji. Jakkolwiek ulokowanie polityki społecznej jako specjalności w ramach nauk o polityce publicznej może być odbierane jako dyskusyjne, to przecież dotychczas usytuowanie polityki społecznej nie było jednoznaczne i wywoływało pewne wątpliwości, zwłaszcza przy okazji prac promocyjnych. Ważniejszy jednak wydaje się fakt, że bliskie sąsiedztwo z innymi specjalnościami w ramach dyscypliny, jaką są nauki o polityce publicznej, a szczególnie z polityką gospodarczą, pozwala na zachowanie wrażliwości polityki społecznej na aspekty ekonomiczne.

\section{Bibliografia}

Aktywizujaca polityka społeczna, red. J. Orczyk, M. Żukowski, „Zeszyty Naukowe” 2007, nr 89, Wydawnictwo Akademii Ekonomicznej w Poznaniu.

Bürgernahe Sozialpolitik. Planung, Organisation und Vermittlung soziale Leistungen auflokaler Ebene, Hrsg. F.-X. Kaufmann, Campus-Verlag 1979.

Caulier-Grice J., Davis A., Patrick R., Norman W., Defining Social Innovation. A deliverable of the project: "The theoretical, empirical and policy foundations for building social innovation in Europe" (TEPSIE), European Commission - 7th Framework Programme, European Commission, DG Research, Brussels 2012.

Cesarski M., Zagadnienia mieszkaniowe i osadnicze w pracach Ludwika Krzywickiego i ich aktualność, „Człowiek i Środowisko” 2010, nr 3-4. 
Grewiński M., Wielosektorowa polityka społeczna. O przeobrażeniach państwa opiekuńczego, WSP TWP, Warszawa 2009.

Hausner J., Zarzadzanie publiczne, Wydawnictwo Naukowe Scholar, Warszawa 2008.

Hochgerner J., Conceptualising social innovation, https://www.zsi.at/attach/Hochgerner_ Madrid_7-3-2012_ppt, dostęp 16.05.2014.

Hrynkiewicz J., Kwestia społeczna w pracach Ludwika Krzywickiego, Wydawnictwo UW, Warszawa 2010.

Kalkulator Społeczny - narzędzie Kalkulatora Kosztów Zaniechania w polityce społecznej, „Polityka Społeczna” 2014, zeszyt tematyczny 3.

Karwacki A., Papierowe skrzydła. Rzecz o spójnej polityce społecznej. Wydawnictwo UMK, Toruń 2010.

Karwacki A., Rymsza M., Meandry upowszechniania koncepcji aktywnej polityki społecznej $w$ Polsce, w: Polityka aktywizacji $w$ Polsce. Ustugi reintegracji $w$ sektorze gospodarki społecznej, red. M. Grewiński, M. Rymsza, Wydawnictwo Wyższej Szkoły Pedagogicznej TWP, Warszawa 2011.

Kaźmierczak T., Rymsza M., Aktywna polityka społeczna. Stan obecny i szanse upowszechnienia koncepcji, „Analizy i Opinie” 2005, nr 48, Instytut Spraw Publicznych, Warszawa.

Kryzys gospodarczy 2008+ test dla stosowanej polityki. Metody przeciwdziałania i ich skuteczność, red. K. Żukrowska, Oficyna Wydawnicza SGH, Warszawa 2013.

Kryzys i co dalej?, red. I. Lichniak, Oficyna Wydawnicza SGH, Warszawa 2012.

Krzeczkowski K., Problemat polityki społecznej, Instytut Spraw Społecznych, Warszawa 1936.

Kubicki P., Życie w społeczności lokalnej, www.firr.org.pl/uploads/PON/08-Zycie-w-spolecznoscilokalnej.doc

Morel N., Palier B., Palme J., Towards a social investment welfare state? Ideas, policies and challenges, The Policy Press University of Bristol, Bristol 2012.

Polityka społeczna, red. A. Kurzynowski, Oficyna Wydawnicza SGH, Warszawa 2001.

Rokicki J., Usługi społeczne jako przedmiot badań (pojęcie, cechy, rodzaje i funkcje), „Polityka Społeczna” 2014, nr 7.

Rychliński S., Lustracje społeczne, Aspra-JR, Warszawa 2001.

Rymsza M., Aktywizacja w polityce społecznej. W stronę rekonstrukcji europejskich welfare states?, Wydawnictwo IFiS PAN, Warszawa 2013.

Szarfenberg R., Miejsce polityki społecznej w polityce publicznej. Ekspertyza na potrzeby projektu Kalkulator Kosztów Zaniechania, Warszawa 2013, maszynopis.

Szarfenberg R., Nauki o polityce społecznej a nauki o polityce publicznej, http://rszarf.ips. uw.edu.pl/pdf/nopp_nops.pdf

Transformacja systemowa w Polsce, red. K. Żukrowska, Oficyna Wydawnicza SGH, Warszawa 2010.

Wokół teorii polityki społecznej, red. B. Rysz-Kowalczyk, B. Szatur-Jaworska, IPS UW, Warszawa 2003. 
Woźnicki J., Nowa dyscyplina - „nauki o polityce publicznej” usytuowana w dziedzinie nauk społecznych, „Nauka” 2012, nr 1.

Zybała A., Państwo i społeczeństwo w działaniu. Polityki publiczne wobec potrzeb modernizacji państwa i społeczeństwa, Wydawnictwo Difin, Warszawa 2013.

Zybała A., Polityki publiczne. Doświadczenia w tworzeniu i wykonywaniu programów publicznych w Polsce i w innych krajach, KSAP, Warszawa 2012. 
